Journal Of Al-Azhar University Engineering Sector

Vol. 14, No. 51, April, 2019, 453-459

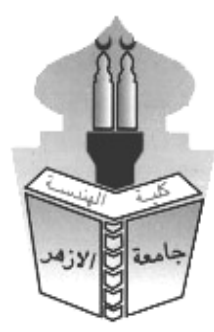

\title{
PREDICTION OF UNCONFINED COMPRESSIVE STRENGTH OF ROCKS BY POINT LOAD STRENGTH INDEX
}

\author{
Mohamed Saad Eldin mohamed ${ }^{1}$, Mohamed A. Saeed ${ }^{1}$ and Nasser A. A. Radwan ${ }^{2}$ \\ ${ }^{\mathbf{1}}$ Faculty Of Engineering - Al-Azhar University, Nasr City, Cairo, Egypt, \\ ${ }^{2}$ Housing and Building National Research Center, Soil Mechanics Inst.
}

\begin{abstract}
The point load testing is widely used to determine rock strength indeces in geotechnical practices as a result to simplicity. The present study presents correlation equations between the unconfined compressive strength $\left(\mathrm{q}_{\mathrm{u}}\right)$ and point load strength index $\mathrm{Is}_{(50)}$ adopted for different types of rocks. In order to estimate a new correlation between the unconfined compressive strength and point load strength test, more than 166 tests were performed. The tests were conducted on four rock types including Sandstone, Siltstone, Limestone and Basalt. The soil samples were collected from different sites along the new administrative capital of egypt. The study shows a reliable correlation between the unconfined compressive strength estimated from the two test approaches.
\end{abstract}

\section{KEYWORDS : Unconfined Compressive Strength $\left(q_{u}\right)$, Point Load Strength Index Is $\mathbf{s}_{(50)}$, Basalt, Limestone, Sandstone, Siltstone.}

\section{INTRODUCTION}

The new administrative capital of Egypt is considered a large-scale project. With the growing construction rates, understanding the compressive strength of rocks in the new capital is become a necessary. one of the most important rock parameters is the unconfined compressive strength $\left(\mathrm{q}_{\mathrm{u}}\right)$. It is used widely in rock classifications such as Rock Mass Rating (RMR) and geotechnical design of various development projects. unconfined compressive strength has been standardized by both the international society of rock mechanics (ISRM) [1],[2] and American society for testing and materials(ASTM) [3],[4]. the method is time consuming and expensive. unconfined compressive strength testing becomes harder due to geometric parameters that they are not allowed by the code to performed on them, or some rocks may fail in the preparation stage before performing the $\left(\mathrm{q}_{\mathrm{u}}\right)$ test there are indirect tests such as Point Load Strength Index that cara be used in predecting the unconfined compressive strength. This test is easier to carry out because it necessitate or no sample preparation and the testing equipment is less sophisticated and can used easily in field. Therefore, the main purpose of this research is to perform empirical relations between unconfined compressive strength $\left(\mathrm{q}_{\mathrm{u}}\right)$ and the point load strength index $\mathrm{Is}_{(50)}$ of various rock types of new administrative capital. the next table 1 shows in detail the core locations in coordinates with a summary about them and shows the contribution of samples by type and contribution of samples by Place where Figure 1 
Table 1: Summary of Borehole Locations and Data

\begin{tabular}{|c|c|c|c|c|c|}
\hline Area & $\begin{array}{l}\text { Stone } \\
\text { name }\end{array}$ & $\begin{array}{l}\text { Maximum } \\
\text { Thickness }\end{array}$ & Latitude & Longitude & $\begin{array}{c}\text { No of } \\
\text { samples }\end{array}$ \\
\hline $\begin{array}{c}\text { Capital } \\
\text { International } \\
\text { Airport } \\
\end{array}$ & Lime Stone & $4 \mathrm{~mm}$ & $30^{\circ} 3^{\prime} 14^{\prime \prime} \mathrm{N}$ & $31^{\circ} 50^{\prime} 24^{\prime \prime E}$ & $\varepsilon r$ \\
\hline $\begin{array}{c}\text { Government } \\
\text { Square }\end{array}$ & Sand Stone & $0.9 m$ & $30^{\circ} 0^{\prime} 49^{\prime \prime} \mathrm{N}$ & $31^{\circ} 45^{\prime} 5^{\prime \prime E}$ & $\overline{\mid r \varepsilon}$ \\
\hline $\begin{array}{l}\text { Iconic } \\
\text { Tower }\end{array}$ & Basalt & $39 m$ & $29^{\circ} 58 ' 55^{\prime \prime} \mathrm{N}$ & $31^{\circ} 44^{\prime} 2^{\prime \prime E}$ & $\Leftrightarrow r$ \\
\hline $\begin{array}{c}\text { Sports } \\
\text { Zone }\end{array}$ & Silt Stone & $0.5 \mathrm{~m}$ & $30^{\circ} 0^{\prime} 16^{\prime \prime} \mathrm{N}$ & $31^{\circ} 35^{\prime} 5^{\prime \prime E}$ & $r \xi$ \\
\hline $\begin{array}{l}\text { Villas } \\
\text { Zone }\end{array}$ & "Lime Stone & $1.7 \mathrm{~m}$ & $30^{\circ} 12^{\prime \prime} \mathrm{N}$ & $31^{\circ} 40^{\prime} 53^{\prime \prime E}$ & rr \\
\hline \multicolumn{5}{|c|}{ Total Number of Samples } & 179 \\
\hline
\end{tabular}

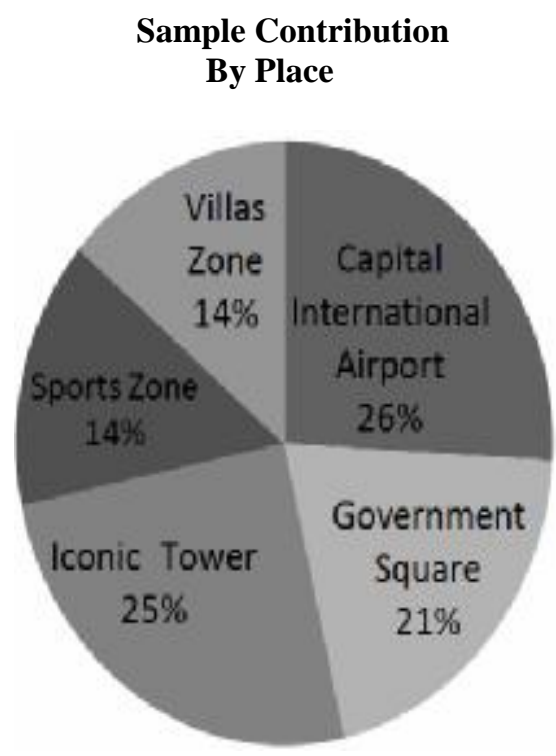

(a)

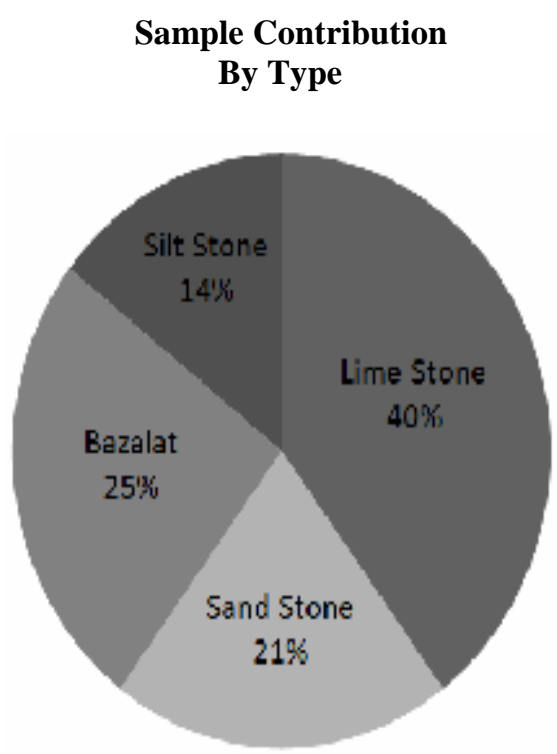

(b)

Figure 1: Sample Contributions (a) by Place, (b) by Rock Type.

\section{PREVIOUS STUDIES}

An interesting study was conducted by Broch and Franklin, 1972 [5] studied the correlation between compressive strength and point load strength of rocks on fifteen rock types. The results being corrected to a reference diameter of $50 \mathrm{~mm}$. Figure 2 shows a straight line correlation whose slope of 23.7 , is rounded to 24 , and corresponds to the ratio of uniaxial compressive strength to point-load strength, averaged for the fifteen rock samples; Mohamad, Edy Tonnizam [6] discussed the relation between unconfined compressive strength and point load strength and expressed this relation by Figure 3 shows a straight line; Singh, T. N., Ashutosh Kainthola, and A. Venkatesh [7] discussed the relation between unconfined compressive strength and point load strength Figure 4 shows that the relation that the relation is different for different rock types, rather than being consistent for all the rock types. This may be due to the anisotropic nature of the rocks as well as their failure behavior under loading condition; ISRM, 1985 [2] has given conversion factors of 20 and 25 between $\left(\mathrm{q}_{\mathrm{u}}\right)$ and $\mathrm{Is}_{(50)}$; numerous studies have investigated the correlations between point load strength 
index Is $\mathrm{s}_{(50)}$ with unconfined compressive strength $\left(\mathrm{q}_{\mathrm{u}}\right)$, the most correlations in literature were summarized in Table 2 , These equations give quite results, although a few of them show wide variation. However, there is a need for more experimental work for better correlation, particularly for different types of rocks.

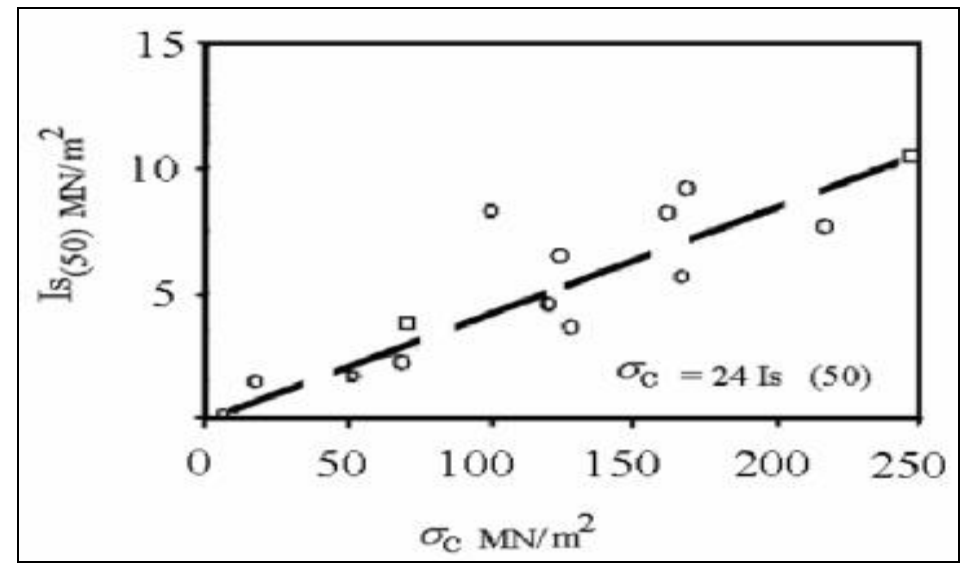

Fig. 2: Relationship between $\left(q_{u}\right)$ and $\left(I_{50}\right)$ by Broch and Franklin

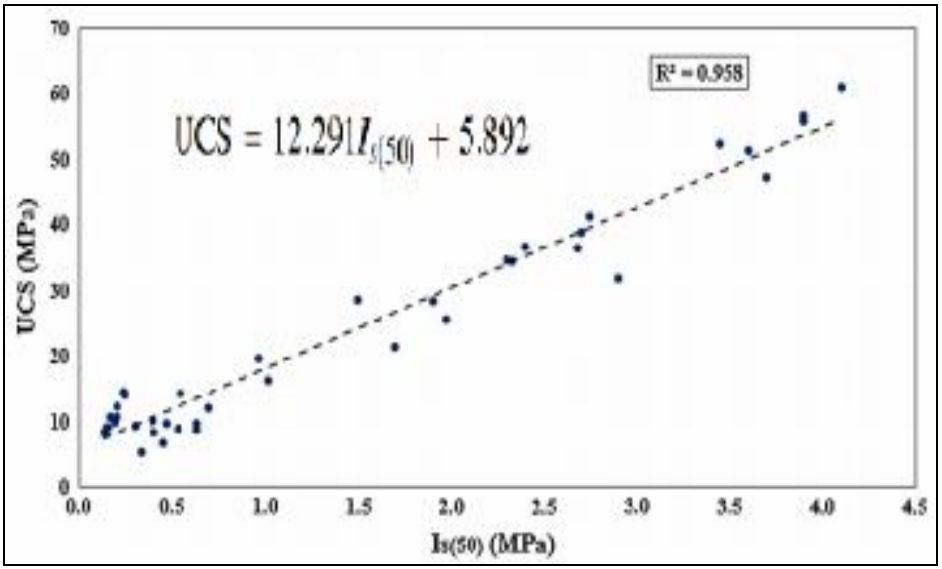

Fig. 3: Relationship between (qu) and (IS50) by Mohamad, Edy Tonnizam

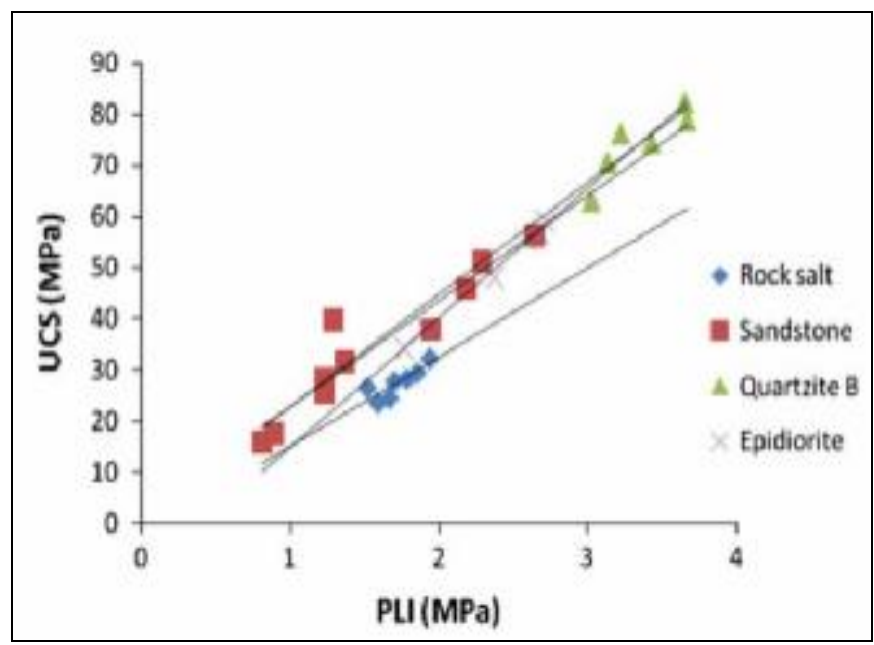

Fig. 4: Relationship between (qu) and (IS50)

by T. N. Singh, Ashutosh Kainthola

Table (2) Correlating equations for $q_{u}$ and $I_{50}$ given by previous researchers 


\section{Experimental Program}

The tested rock samples were collected from various sites located at the city of the new administrative Capital, Egypt. unconfined compressive strength tests were performed with accordance ASTM D7012-14[1] at Housing and Building National Research Center (HBRC), and the samples had length to diameter $\geq 2$. UCS value is determined by the following equation: -

$$
\mathrm{q}_{\mathrm{u}}=\frac{P}{A}
$$

Where peak load (p) to initial cross sectional area (A).

Moreover, Is $(50)$ tests were carried out with accordance ASTM D5731-16 [4] by diametral method, the point load is considered an index text, and it allows the determination of the uncorrected point load strength index, which must then be corrected to the standard equivalent diameter $\left(D_{\mathrm{e}}\right)$ of $50 \mathrm{~mm}$ Peng and Zhang, 2007 [21]. Four types of rocks were used in experiment, coming from different locations of new administrative Capital of Egypt, Is $\mathbf{s}_{(50)}$ value is determined by the following equation: -

$$
\mathrm{Is}_{(50)}=\mathrm{F} \times \mathrm{I}_{\mathrm{s}}
$$

the "size correction factor F" can be obtained from the chart in fig. 5, or from the expression:

$\mathrm{Is}=\mathrm{P} / \mathrm{D}^{2} \mathrm{e}, \mathrm{MPa}$

$$
\mathrm{F}=\left(\mathrm{D}_{\mathrm{e}} / 50\right)^{0.45}
$$

$\mathrm{I}_{\mathrm{S}}=$ Uncorrected point load strength index

$\mathrm{p}=$ failure load, $\mathrm{N}$

$\mathrm{F}=$ Size Correction Factor

$\mathrm{D}^{2} \mathrm{e}=\mathrm{D} \times \mathrm{D}^{\prime}$ for cores, $\mathrm{mm}^{2}$

\begin{tabular}{|c|c|c|c|}
\hline Author(s) & Country & Rock type & Correlating equations \\
\hline [5] Broch and Franklin (1972) & UK & Various & $\mathrm{UCS}=23.7 \mathrm{Is}_{50}$ \\
\hline [6] Mohamad, Edy Tonnizam & - & $\longrightarrow$ & UCS $12: 291$ Is $50+5: 892$ \\
\hline [У] T. N. Singh, Ashutosh Kainthola & - & Various & $\mathrm{UCS}=14-24 \mathrm{Is}_{50}$ \\
\hline [ץ] ISRM (1985) & $\longrightarrow$ & $\longrightarrow$ & $\mathrm{UCS}=20-25 \mathrm{Is}_{50}$ \\
\hline [8] Bieniawski (1975) & South Africa & Sandstones & $\mathrm{UCS}=23.97$ Is50 \\
\hline [9] Hassani et al. (1980) & UK & Sedimentary rocks & $\mathrm{UCS}=29 \mathrm{Is}_{50}$ \\
\hline ['·] Read et al. (1980) & Australia & Sedimentary rocks & $\mathrm{UCS}=20 \mathrm{Is}_{50}$ \\
\hline [1'] Hawkins and Olver (1986) & $\overline{\mathrm{UK}}$ & Limestone & $\mathrm{UCS}=26.5 \mathrm{Is}_{50}$ \\
\hline [12] O'Rourke (1988) & USA & Sedimentary & $\mathrm{UCS}=30 \mathrm{Is}_{50}$ \\
\hline [13] Vallejo et al. (1989) & USA & Sandstone & $\mathrm{UCS}=17.4 \mathrm{Is}_{50}$ \\
\hline [14] Singh and Singh (1993) & India & Quartzite & $\mathrm{UCS}=23.4 \mathrm{Is}_{50}$ \\
\hline [15] Das (1985) & Canada & Siltstone & $\mathrm{UCS}=14.7 \mathrm{Is}_{50}$ \\
\hline [16] Smith (1997) & Various & Pandstone/limestone & $\mathrm{UCS}=24 \mathrm{Is}_{50}$ \\
\hline [17] Rusnak and Mark (1999) & USA & Shale & $\mathrm{UCS}=21.8 \mathrm{Is}_{50}$ \\
\hline [18] Kurtulus, C., A. Bozkurt, H. Endes(2012) & Turkey & Various & $\overline{\mathrm{UCS}}=14,458 \mathrm{Is}_{(50)}+0,3852$ \\
\hline [19] Salah, Maher, Abdallah(2014) & United Arab & Sandstones & UCS = 11.24 $\mathrm{Is}_{(50)}$ \\
\hline [20] Ehsan Momeni, Ramli Nazir(2015) & Malaysia & - & UCS $(\mathrm{MPa})=13.54 \mathrm{Is}_{(50)}+14.93$ \\
\hline
\end{tabular}

$\mathrm{De}=$ equivalent core diameter $=\mathrm{D}$ for diametral tests

Table (2) Correlating equations for $q_{u}$ and $I_{50}$ given by previous researchers 


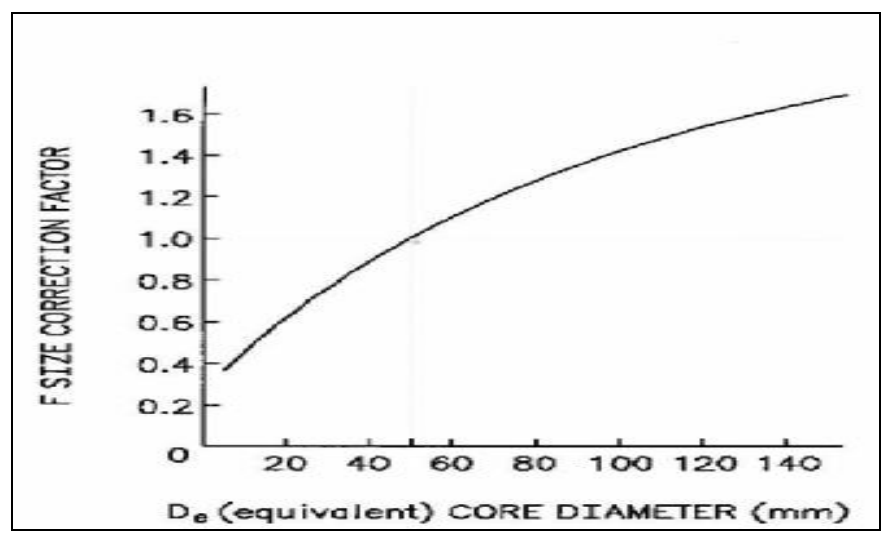

FIG. 5 Size Correction Factor Chart

\section{TEST RESULTS AND DISCUSSION}

In order to estimate with new correlation between unconfined compression strength and point load test, to achieve the proposed objectives of the study, more than 166 tests were performed all samples were acquired from the of new administrative capital of Egypt. Regression equations were established among rock parameters and correlations were expressed The plots of $\mathrm{q}_{\mathrm{u}}$ versus Is $\mathrm{s}_{(50)}$ in Figs. 6, 7, 8,9 clearly indicate that the relation is dissimilar for different rock types ,this may be attributed to mineralogical, textural, and deformational factors. There is a linear correlations between the compressive strength, point load strength index. The average values of the correlation coefficient $\left(\mathrm{R}^{2}\right)$ is 0.90 , that it indicates a fairly strong correlation.

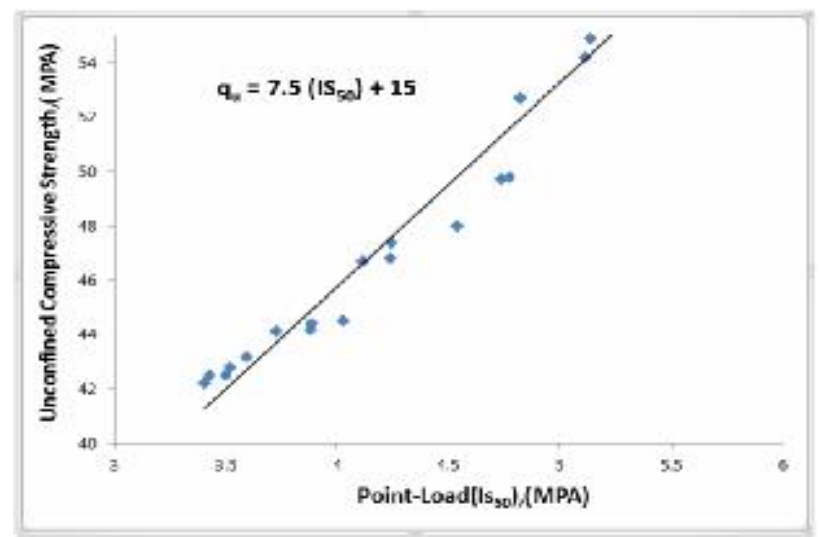

Fig. 6: Relationship between $\left(\mathrm{q}_{u}\right)$ and $\left(\mathrm{IS}_{50}\right)$ for Basalt rock

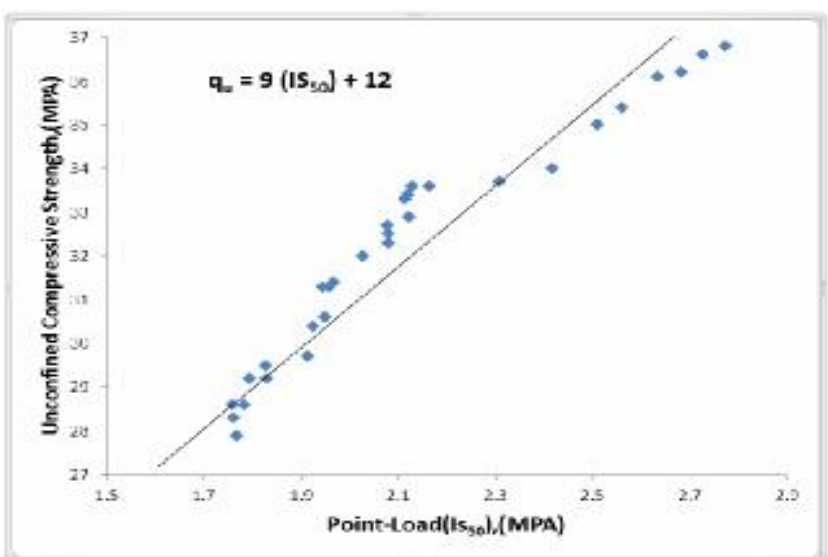

Fig. 7: Relationship between (qu) and (IS50) for Lime Stone rock 


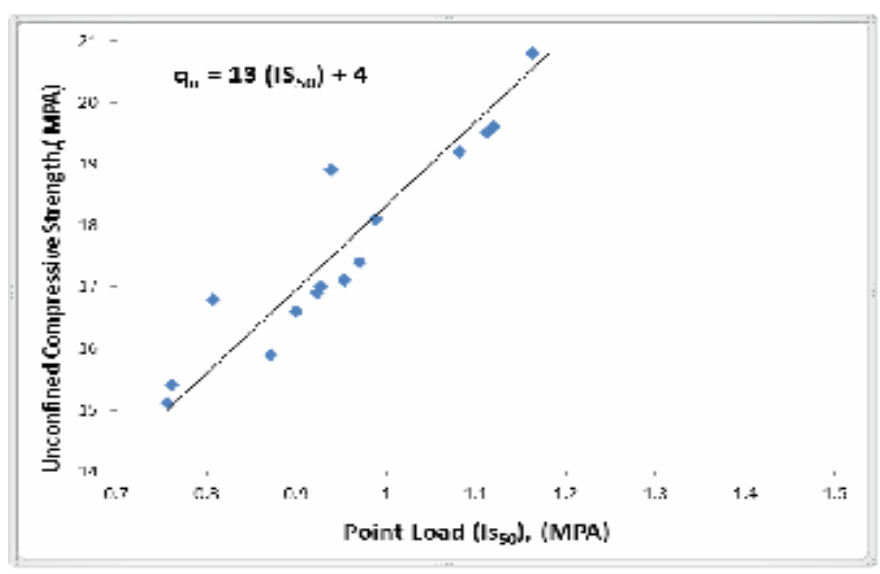

Fig. 8: Relationship between $\left(\mathrm{q}_{\mathrm{u}}\right)$ and $\left(\mathrm{IS}_{50}\right)$ for Sand stone rock

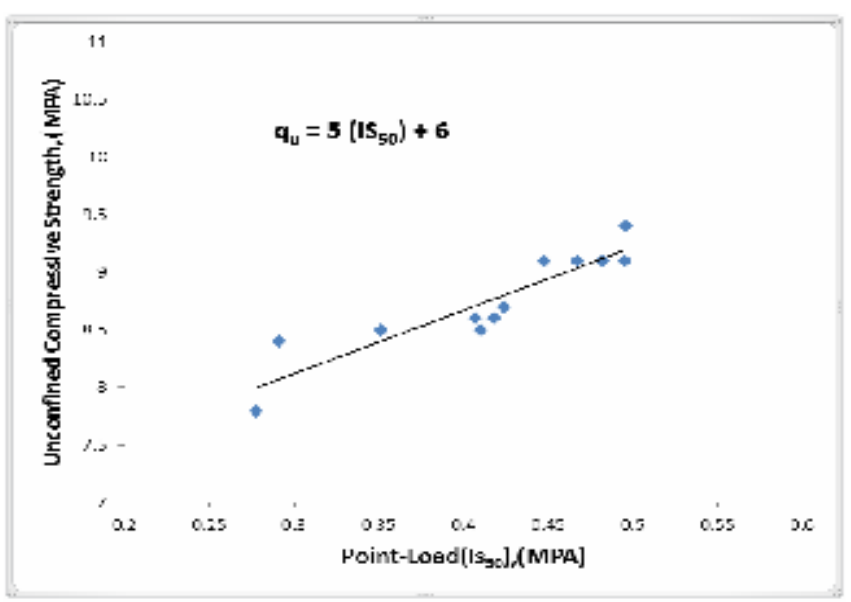

Fig. 9: Relationship between $\left(q_{u}\right)$ and $\left(\mathrm{IS}_{50}\right)$ for Silt stone rock

\section{Conclusions}

a- There is a linear correlation between the unconfined compressive strength and point load strength index for the tested rocks.

b- This study for different types of rocks to predict unconfined compressive strength using Point Load Strength Index.the following con be concluded as follows:-

1- The Relationship between $\left(\mathrm{q}_{\mathrm{u}}\right)$ and $\left(\mathrm{IS}_{50}\right)$ for Basalt is:

2- The Relationship between $\left(\mathrm{q}_{\mathrm{u}}\right)$ and $\left(\mathrm{IS}_{50}\right)$ for Lime Stone is:

$$
\mathrm{q}_{\mathrm{u}}=7.5\left(\mathrm{IS}_{50}\right)+15
$$

3- The Relationship between $\left(\mathrm{q}_{\mathrm{u}}\right)$ and (IS $\left.{ }_{50}\right)$ for Sand Stone is:

$$
\mathrm{q}_{\mathrm{u}}=9\left(\mathrm{IS}_{50}\right)+12
$$

4- The Relationship between $\left(\mathrm{q}_{\mathrm{u}}\right)$ and (IS $\left.{ }_{50}\right)$ for Silt Stone is:

$$
\mathrm{q}_{\mathrm{u}}=13\left(\mathrm{IS}_{50}\right)+4
$$

$$
\mathrm{q}_{\mathrm{u}}=5\left(\mathrm{IS}_{50}\right)+6
$$

\section{REFERENCES}

[1] ISRM (1979) Suggested methods for determining the uniaxial compressive strength and deformability of rock materials. Int J Rock Mech Min Sci 16(2):135-140

[2] ISRM (1985) Suggested method for determining point load strength. Int J Rock Mech Min Sci Geomech(Abstract) 22(2):51-60

[3] ASTM D7012 - 14e1 Standard Test Methods for Compressive Strength and Elastic Moduli of Intact Rock Core Specimens under Varying States of Stress and Temperatures 
[4] ASTM D5731 - 16 Standard Test Method for Determination of the Point Load Strength Index of Rock and Application to Rock Strength Classifications.

[5] Broch, E., and J. A. Franklin. "The point-load strength test." International Journal of Rock Mechanics and Mining Sciences \& Geomechanics Abstracts. Vol. 9. No. 6. Pergamon, 1972.

[6] Mohamad, Edy Tonnizam, et al. "Prediction of the unconfined compressive strength of soft rocks: a PSO-based ANN approach." Bulletin of Engineering Geology and the Environment 74.3 (2015): 745-757.

[7] Singh, T. N., Ashutosh Kainthola, and A. Venkatesh. "Correlation between point load index and uniaxial compressive strength for different rock types." Rock Mechanics and Rock Engineering 45.2 (2012): 259-264.

[8] Bieniawski, Z. T. "The point-load test in geotechnical practice." Engineering Geology 9.1 (1975): 1-11.

[9] Hassani, F. P., M. J. Scoble, and B. N. Whittaker. "Application of the point load index test to strength determination of rock and proposals for a new size-correction chart." The 21st US Symposium on Rock Mechanics (USRMS). American Rock Mechanics Association, 1980.

[10] Read, J. R. L., P. N. Thornton, and W. M. Regan. "A rational approach to the point load test." Third Australia-New Zealand conference on Geomechanics: Wellington, May 1216, 1980. Institution of Professional Engineers New Zealand, 1980.

[11] Hawkins, A. B., and J. A. G. Olver. "Point Load Tests: Correlation Factors and Contractual Use. An Example from the Corallian at Weymouth." Geological Society, London, Engineering Geology Special Publications 2.1 (1986): 269-271.

[12] O'rourke, M., et al. "Limitation of myocardial infarction by early infusion of recombinant tissue-type plasminogen activator." Circulation 77.6 (1988): 1311-1315.

[13] Vallejo, Luis E., Robert A. Welsh Jr, and Michael K. Robinson. "Correlation between unconfined compressive and point load strengths for Appalachian rocks." The 30th US Symposium on Rock Mechanics (USRMS). American Rock Mechanics Association, 1989.

[14] Singh, V. K., and D. P. Singh. "Correlation between point load index and compressive strength for quartzite rocks." Geotechnical and geological Engineering 11.4 (1993): 269272.

[15] Das, B. M. "Evaluation of the point load strength for soft rock classification." Proceeding of the 4th International Conference on Ground Control in Mining. Morgantown, WV. 1985.

[16] Smith, Hardy J. "The point load test for weak rock in dredging applications." International Journal of Rock Mechanics and Mining Sciences 34.3-4 (1997): 295-e1.

[17] Rusnak, John, and Christopher Mark. "Using the point load test to determine the uniaxial compressive strength of coal measure rock." Proceedings of the 19th international conference on ground control in mining. Morgantown, WV: West Virginia University. 1999.

[18] Kurtulus, C., A. Bozkurt, and H. Endes. "Physical and mechanical properties of serpentinized ultrabasic rocks in NW Turkey." Pure and applied geophysics 169.7 (2012): 1205-1215.333.

[19] Salah, Hussain, Maher Omar, and Abdallah Shanableh. "Estimating unconfined compressive strength of sedimentary rocks in United Arab Emirates from point load strength index." Journal of Applied Mathematics and Physics 2.06 (2014): 296.

[20] Momeni, Ehsan, et al. "Prediction of unconfined compressive strength of rocks: a review paper."Jurnal Teknologi 77.11 (2015): 43-50.

[21] Peng, Suping, and Jincai Zhang. Engineering geology for underground rocks. Springer Science \& Business Media, 2007. 